Mózes Dóra

Debreceni Tudományegyetem

\title{
A fekete maszkulin flâneurség, városi hangtájképek és nemfehér nők hangjai Teju Cole Open city címü regényében
}

Jelen cikk a fekete maszkulin flâneurség fogalmát körvonalazza: nagyvárosi környezetben vizsgálja a flâneur rasszal és genderrel összefüggő sajátos élményeit, illetve gyakorlatait. A szociolingvisztika társas-konstruktivista poszthumanista megközelítése (Pennycook 2018), a fekete- (Glissant 1989; Crawley 2017) és a hangkultúrával (Stoever 2016; LaBelle 2010, 2018; Voegelin 2010) kapcsolatos tanulmányok megkérdőjelezik a vizualitás, a látható másság kizárólagos kategorizáló szerepét, a rassz és a gender fogalmát pedig (verbális és nem verbális eszközökkel kifejezett) nyelvi, szemiotikai (Kandiah 1998), illetve szonikus (re)konstrukcióként konceptualizálják. A butleri performativitás fogalomhoz kapcsolódóan a rekonstrukció azt jelzi, hogy a beszélők alkotó nyelvi tevékenysége képes újraalkotni, átformálni az adott társadalomban érvényes ideológiai jelentéseket. A cikk ezen értelmezési kereteket alapul véve a fekete flâneurség szonikus megalkotásának megjelenítésére és problematikájára fókuszál kortárs amerikai író Teju Cole Open City című regényében a főszereplő és narrátor figuráján keresztül. Mivel az elemzés alapvetően a fekete férfinek, Juliusnak a perspektívájára fókuszál, szükségképpen kitér a fekete és a fehér flâneur közötti különbségek komparatív vizsgálatára is. Mindezen szempontokat a városi térhez kapcsolva kutatásom a következő részkérdésekre keresi a választ: (1) mennyiben múködnek a városi térben a zenei, szóbeli és más szonikus elemek olyan traumák indexeként, mint a rasszista és patriarchális elnyomás, a gyarmatosítás, az amerikai indián vagy a ruandai genocídium, a nemi erôszak; (2) hogyan találkozik a hang és a tér a rassz és a gender keresztmetszetében, mit árulhatnak el ezek a kapcsolatok a városi helyszínek és szubjektumok akusztikai és társas-társadalmi viszonyairól; (3) hogyan artikulálják a fekete flâneurnek a különböző női figurákhoz és kifejeződési formákhoz fűződő viszonyát, érzéseit a különböző szonikus elemek (a különböző zenei formák, hangok, zajok, beszédtettek és a csend). 


\section{Bevezetés}

A flâneurség tárgyában folytatott korábbi kutatásaim ${ }^{1}$ igazolták, hogy a fekete flâneurség meghatározó attribútumának tekinthető a városi környezetből származó hangingerekre való fokozott figyelem, az ún. odahallgatás ${ }^{2}$ (listening). A fekete flâneurség alapvetően szonikus felfogásából kiindulva jelen tanulmány annak elemzését helyezi fókuszba, hogy az urbánus hangtájképek ${ }^{3}$ szonikus jelei hogyan alkotják, hozzák létre a különböző terekhez és nemek közötti (crossgender) szituációkhoz kötött személyes és kollektív jelentéseket, illetve miként hatnak a flâneur maszkulin identitáspozíciójára.

A magyar szakirodalomban tudomásom szerint interszekcionális keretben a maszkulin fekete flâneurség és a szonikus észlelés összefüggéseivel még senki nem foglalkozott. Pataki Éva Nirpal Singh Dhaliwal Tourism címú regényének vizsgálatában amellett érvel, hogy a flâneurség a brit-ázsiai identitásnak és diaszpóratapasztalatnak sajátossága (2014). Györke Ágnes Doris Lessing múveiben London transznacionális terének kezelését a flâneurség fogalmán keresztül konceptualizálja (2017, 2019). Kutatásaim újdonsága a korábbi elemzésekhez képest, hogy cikkemben a fekete flâneurség egy kortárs formáját térképezem fel: nem a fehér flâneur modernségre való törekvésének problematikáját állítom a figyelem előterébe, hanem egy regény szövegének elemzésén keresztül azt vizsgálom meg, mit jelent fehér térben fekete férfiként modernnek ${ }^{4}$ lenni. Míg a párizsi flâneur céltalan sétái, elidegenedése és szimbolikus hontalansága a fehér férfinek a térhez való jogán, a térben való szabad mozgásán és más patriarchális kiváltságain alapszik, a fekete flâneurség szükségszerűen magában foglalja a fekete lét

${ }^{1}$ Jelen cikk a fekete flâneurséget szonikusan konceptualizáló tanulmányom (ld. Mózes 2020) továbbgondolásaként a fekete flâneurséget a rassz és a gender keresztmetszetében, a magyar tudományos érdeklődőknek magyar nyelven mutatja be.

${ }^{2}$ A fekete (Black Studies) és a hangkultúrával (Sound Studies) kapcsolatos tanulmányokban kulcsfontosságú listening terminusnak nincs magyar megfelelője, így helyette itt és a szó minden további előfordulása esetében az odahallgatást használom. Ez a terminus azt a folyamatot jelöli, melynek során a szonikus források percepciója, észlelése érzelmi élmények keltése mellett a tudatkereten belül is mozgósít, aktivizál kognitív és emlékező műveleteket. Az értő odahallgatás feltételezi, hogy a hallgató fél rendelkezik a hangok dekódolásához szükséges kontextuális háttér szociokulturális ismereteivel.

3 Schafer hangtájképnek (soundscape) nevezi a mindannyiunkat körülvevő és folyamatosan kibontakozó akusztikus környezetet, amelyben különböző hangforrások találkoznak.

${ }^{4}$ Ahogy Toni Morrison fogalmazott Paul Gilroy-val készített interjúban: „a fekete embereket a rabszolgaság tapasztalata az első igazán modern emberekként jelöli meg” (1993, 178). Az idézőjelek között megjelenő (adott esetben Gilroy idézett munkájából származó) kifejezéseket a saját fordításomban közlöm. Amennyiben az idézethez kapcsolódó bibliográfiai tétel nem tüntet fel fordítót, az idézetek a cikk további szövegrészeiben is a saját fordításaim (M.D.). 
hontalanságának, elidegenedésének és tárgyiasításának formáit. ${ }^{5}$ A fekete flâneurség a tér és a szubjektivitás performatív produkciója, a racializált tér akusztikai és térbeli átírása, ellenpontozása, amely egy „migrációs vagy metaforikus" szöveget helyez a „tervezett és olvasható város” raciálisan strukturált szövegére (de Certeau 1984, 93).

Az Open City Teju Cole kortárs nigériai-amerikai író, esszéíró, fotós és mûvészettörténész kísérteties regénye, mely 2011-ben jelent meg. ${ }^{6}$ A regény központi karaktere és narrátora, Julius nigériai és német gyökerekkel rendelkező amerikai pszichiátriai rezidens, aki céltalanul bolyong a mai New York és Brüsszel utcáin. A városokban tett sétái során barátok és idegenek egész katalógusával találkozik, fiatalkori Nigériájának emlékein és páciensei életútján tűnődve a raciális kapitalizmus történetéről és annak utóéletéről elmélkedik. A regény magában foglalja a narratív jelent, és elkalandozik Julius vagy beszélgetőtársai elbeszélt emlékeinek idősíkjaiban is. Bizonyos értelemben az afropolita értelmiségi emblémája, szinte megszállottan, fantasztikus precizitással tudósít a legkülönbözőbb jelenségekről, például John Brewster siket festő portréiról, a palesztin megszállásról, a költöző madarakról, Paul de Manról és az alsó-manhattani afrikai temetőről. Intenzív munkája és barátnőjével való szakítása hatására még inkább magába zárkózik, érzéketlen hangvétele növekvő magányát és melankóliáját tükrözi. Miközben jellemzően keresi a nálánál magasabb presztízsű pozíciókban lévő értelmiségiek (például mentora, korábbi angol professzora, Dr. Saito) társaságát, az alacsonyabb státuszú, alárendelt karakterek felé irányuló rasszalapú kulturális vagy politikai elköteleződés elől kitér (1. pl. Chude-Sokei 2014, 66). (Például azzal bánt meg egy afrikai származású taxist, hogy nem elegyedik vele szóba.) Cole tehát mindvégig megkérdőjelezi a pszichiáter önképét, melyet önmagáról mint „együttérző afrikairól”” alkotott (Cole 2012, 70). Az utolsó előtti fejezetben azonban váratlan és drámai fordulatként felszínre kerül, hogy Juliust egy gyermekkori nigériai ismerőse, Moji nemi

${ }^{5}$ Elemzéseim során a fekete flâneur/ség megnevezést minden esetben az interszekcionális megközelítésnek megfelelően használom, és - ennek megfelelően - Julius flâneurségét a rassz, a gender, a szexualitás és a társadalmi osztály keresztmetszetében elemzem. Tehát a tanulmányban a flâneurség vizsgálata a cisz heteroszexuális férfi értelmiségi fekete flâneurre korlátozódik, nem foglalkozom a flâneurség női, queer, transz, szubaltern stb. formáival. A továbbiakban ezt nem minden esetben jelzem külön.

${ }^{6}$ Cole az Every Day is for the Thief (2007), amelynek narrátora nagyon hasonlít Juliusra, az esszékollekció Known and Strange Things (2016), valamint egy fényképes napló, Blind Spot (2017) szerzője, amelyben flâneurként utazza körbe, dokumentálja és kommentálja a világ városait.

${ }^{7}$ Cole Open City című regényéből származó idézetek saját fordításaim. A magyar fordítás nyilvánvalóan nem képes az eredeti szöveg nyelvi sajátosságainak visszaadására. Ezért, amennyiben elengedhetetlenül szükséges, az idézett szöveget vagy annak releváns kifejezéseit eredetiben is meg fogom adni. 
erőszakkal vádolja. Ezzel az egész narratíva, tehát Julius hitelessége megkérdőjeleződik: ironikus, hogy az olvasó egy olyan pszichiáterrel találja magát szemben, aki nem ismeri önmagát sem.

A XIX. századi Párizsban csatangoló, tétlenül járkáló flâneur figurája Walter Benjamin Charles Baudelaire és a The Arcades Project (1997, 2002) címú müveiben jelenik meg. Charles Baudelaire The Painter of Modern Life (2010) című könyvében Constantin Guys festőt szintén flâneurnek tekinti. A flâneurség a megfigyelés, a fogyasztás és a műértés fehér, maszkulin formája, amelynek előfeltétele a burzsoázia jóléte és szabadideje. Benjaminnak a flâneurrel kapcsolatos észrevételei testesítik meg a húszas évek kapitalizmusának válságait: az árukapitalizmus idején az élmények (Erfahrung) hervadását, valamint a polgári költő növekvő elidegenedését és ambivalenciáját, aki tájképpé alakítja a bekószált és megbámult városi tereket. Julius elszigetelt lényének, folyamatos gondolati, idő- és térbeli kószálásának, valamint történelmi éleslátásának és saját történetével szembeni vakságának/siketségének megértéséhez is célszerű ezt a megközelítési módot alkalmazni. Napjaink fekete férfi flâneur figurája sokban különbözik a fehér maszkulin flâneurtől, így a fekete flâneur maszkulin alakja hozzásegíthet az urbánus (hang)tájképek, a raciális és a genderelnyomás összefüggéseinek megértéséhez. A fekete flâneurség fokozottan előtérbe tolja a nagyvárosi fenyegetettség és élvezet, valamint a szabad és korlátozott mozgás ambivalenciáját. Két éve fordult elő, hogy egy Starbucks üzletvezetője kihívta a rendőröket két fekete férfi jelenléte miatt, akik a kávézóban a barátjukra vártak. Erre a jellemző raciális incidensre reagálva Cole így fogalmazott: „Ezért mondom mindig azt, hogy nem lehetsz fekete flâneur. A flâneurség a fehéreké. Fehér terepen a feketéknek a teljes tér feszültséggel terhelt." ${ }^{8}$ Ennek ellenére elemzésem fő célkitűzése, hogy a fekete flâneurség jellegzetességeit vizsgálja - egyetértve Cole-lal abban, hogy a fehér szupremácia tereiben a fekete flâneurség mindig ingatag, feszültségekkel terhes és veszélyekkel teli.

A fekete férfi, mint flâneur viselkedésének elemzése során, a különböző hatalmi és elnyomó struktúrák közötti dinamikus kölcsönhatások értelmezésekor a fekete tanulmányok (Fanon 1968, Sexton 2017) mellett a fekete feminista elméleti keretet (Keeling 2009, Sharpe 2016) tekintem irányadónak. A feminista elméletben e dinamikus kölcsönhatások leírásának kulcsfogalma az interszekcionalitás. A terminust Kimberly Crenshaw fekete feminista jogtudós vezette be $(1989,1991)$. Crenshaw érvelésének kiinduló tézise szerint a rasszizmus és a szexizmus összefonódott rendszerei a fekete nőket a polgárjogokban és a polgárjogi mozgalmakban egyaránt láthatatlanná teszik, ezért az érintettek képtelenné válnak jogaik érvényesítésére. A jogász

8 Teju Cole [@_tejucole], Instagram-bejegyzés, 2018. április 15., letöltve az URL-ről. Cole azóta törölte ezt a bejegyzést és még sok másikat. 
további alapvetése, hogy a fekete nőket ért diszkrimináció vizsgálatában a feminista megközelítés nem elégséges, mivel az ilyen egydimenziós, genderszempontú vizsgálatok érdeklődési köre a női csoport privilegizált tagjainak - tehát adott esetben a fehér nőknek - a tapasztalataira korlátozódik. A rassz és a gender egymástól elkülönülő kategóriaként való értelmezése és kezelése nem alkalmas a fekete nők specifikus elnyomásának és alárendeltségének konceptualizációjához (Crenshaw 1989, 40). Az interszekcionalitás fogalmát középpontba helyező megközelítés és a hozzá kapcsolódó módszertan új kutatási paradigmává vált, mely az identitás megértése helyett elsősorban a különböző hatalmi rendszerek (pl. a rassz/etnicitás, a gender, a szexualitás és a társadalmi osztály) interakcióinak, kölcsönhatásának feltérképezésére irányul.

Mindezt tekintetbe véve elemzésem során a fekete flâneur maszkulin figuráját ebben a szemléleti keretben értelmezem: Julius kétségtelenül a rasszizmus áldozata, ugyanakkor - a felbukkanó nemfehér nőkkel9 ellentétben - heteropatriarchális kiváltságokkal rendelkezik. Fontos célkitűzésem megvizsgálni, hogy a nemi rendben fölérendelt pozícióban levő Julius elsősorban a szonikus (tehát elsődlegesen nem a vizuális, bár a gyakorlatban a többi érzékszervvel dinamikus kapcsolatban álló) érzékelésen keresztül, hogyan kapcsolódik az alárendelt pozícióban levő nemfehér nőkhöz és milyen módon konstruálja meg a becsatangolt városi tereket.

\section{A diabolus és a hiphop szonikus párbeszéde}

Brüsszeli tartózkodása során - melynek célja, hogy távolszakadt német nagyanyját felkutassa - Julius egyedül találja magát a Notre Dame de la Chapelle-ben. Az első benyomása a teljes csend. Amint fülei hozzászoknak a nyugodt környezethez, meghallja a zenét, melyet első hallásra jellegzetes barokk ornamentális darabnak gondol. Ugyanakkor észreveszi a „disszonanciát az orgona zene hangzásában”, valamint a zenében fellelhető „elkülönülő szökevény hangokat” (Cole 2012, 138). Így a zene átalakul, Peter Mawell Davies „O God Abufe” című darabjára emlékezteti őt. Megjegyzi, hogy: „Rendkívül alacsony volt a hangerő [...], amikor hallottam a zenében a tritónusz határozottan felkavaró félhangjainak ismétlődését, a melódia nehezen volt megfogható" (Cole 2012, 138). Amikor rájön arra, hogy a zene nem élő, hanem felvételről szól, akkor felismeri a hangzásban a törés forrását:

${ }^{9}$ Érdeklődésre tarthat ugyan számot Dr. Maillotte, a fehér belga származású doktornő iránti figyelme, terjedelmi korlátok miatt nem áll módomban kitérni ennek elemzésére. 
egy kis sárga porszívó. A gép magas hangú zúgása és a felvett orgonazene keveredett és létrehozta a diabolus in musica-t. A takarító nő nem nézett fel a munkájából [...]. Folytatta, teljesen elmélyedt benne, és az orgona zene a porszívó hangja egyetlen, hullámzó zúgássá szövődött össze. (Cole 2012, 138)

Amikor kideríti, hogy a „,ört, szétszórt érzés” (Cole 2012,138) oka az orgonazenének és a porszívó zúgásának a találkozása, az ily módon két különböző hangforrásból összefonódó zenei nyalábot ${ }^{10}$ a tritónusz zenei szakkifejezésből kiindulva a diabolus terminussal nevezi meg. A tritónusz (bővített kvart/szűkített kvint, becenevén diabolus) három egészhangnyi távolság, melyet a középkorban annyira disszonánsnak véltek, hogy betiltották, vagy szigorúan korlátozták. A későbbiekben a romantikus zeneszerzők és jazz-zenészek a feszültség forrásaként ünnepelték (The Harvard Dictionary of Music 2003, 911). A diabolus jelző használata többrétegú értelmezési lehetőségek forrása. Utalhat a templom falain belül, a szent liturgiához tartozó áhítatot és megrendülést kiváltó egyházi orgona zene és a porszívó hangja közötti bináris oppozícióra, ördöginek nevezve tehát a szakrális és a profán, szentségtelen közötti találkozást, egybeolvadást. Az európai római katolikus templomban mint fehér hegemón raciális térben a két fekete test kontroll nélküli jelenléte már önmagában feszültséget, zavart keltő. A diabolus egyik szála a porszívó zúgása, tehát a takarítás nemi racializájónak (nyugaton a háztartási munkát végzők többsége nemfehér nő) visszhangja és ezáltal a láthatatlan, jelentéktelen, eldobható női dolgozókat indexálja. A zúgás felborítja mind a hagyományosan szigorú szabályokat követő európai egyházi zene tonalitásának szabályait, mind Julius hallását, aki bevallja, hogy a létrejött tritónusz ellenáll a kategorizációnak. Ez a kategorizálhatatlanság egyben utal a neokolonialista Belgiumban a fekete menekültet/migránst/bevándorlót jellemzô társadalmon kívüliségre, kétes státuszra is. A fekete zaj a fúgás mú részévé válik: az orgonazene beépül az „extrém zaj látszólagosan értelmetlen textúrájába" (Glissant 1989, 124), mely feloldja a művészet és az élet, a zene és a zaj, a munka és az expresszió közötti megkülönböztetéseket. A fekete zaj folyamatosan átalakuló akusztikája olyan tiltott és nyugtalanító hangeffektusokat produkál, mint a diabolus a középkorban. Ahogyan az ördögi, fúgás, számkivetett hangzás megzavarja a nyugati zene tiszta harmóniáit, a zaj tritónikus és transzszubsztanciális zenévé alakul át, mely a feketeség és a nyugati fehér civilizáció közötti feszültségtől vibrál. A zaj megerősíti a feketeségnek a fehér intézményiséghez való titkos közelségét, a fehér lelkész

10 Deleuze és Guattari terminushasználatát alapul véve a nyaláb napjaink nyelvhasználati gyakorlataiban a különböző nyelvi, térbeli, történeti, tárgyi forrásoknak az adott térben és időben összegyúlt komplex együttesét jelenti (Pennycook 2018, 107). 
lépésének hangját „hangtalanná” teszi (Cole 2012, 140). A fehér flâneur elidegenítő tekintetével szemben a fekete zajnak való kitettség Julius részéről egy olyan kapcsolatot hoz létre az ismeretlen nővel, mely nem a humanizmus, nem az emberi jogok logikájára épül. Amikor Julius elhalad a zajt keltő nő mellett, akkor „bólint neki a fejével” (Cole 2012, 140). A fehér terekben a feketék, többnyire a fekete férfiak közötti bólintás a szolidaritás kifejeződése, itt a templom történetileg fehér terében ez a gesztus szimbolizálja Julius és az ismeretlen nő feketeségben való összetartozását.

Ennek az afro-szonikus eseménynek a hatása alatt Julius folytatja töprengését a templomban porszívózó nőről. Feltételezte, hogy képes megállapítani a nemzetiségét, mert azt gondolta, hogy Belgiumban minden afrikai kongói. Egy éjszakai szórakozóhelyen azonban a fekete tánc és zene hatására elvesztette a nagyvárosi élet detektívjeként (Benjamin 2002, 442) érzett magabiztosságát. A zenei élmény és az önfeledten táncoló fiatalok látványa jelzi, hogy a hiphop rég az amerikai fekete városi teret, földrajzi és etnokulturális határokat átlépő transznacionális irányzattá és gyakorlattá vált. Miközben magányosan iszik és figyeli a fiatal, divatos, egymással flörtölő afrikaiakat, úgy véli, mindannyian kongói származásúak. Amikor rájön, hogy mindenki ruandai, a tér hirtelen elnehezül körülötte: „Olyan volt, mintha a tér hirtelen elnehezült volna ezeknek az embereknek magukkal hordozott történeteivel" (Cole 2012, 139). A ruandai fiatalokat Julius tekintete beskatulyázza az áldozat kategóriájába, traumatikus múltjukat továbbviszi a jelenbe, bezárva óket pszichikai traumájukba. Mindazonáltal az amerikai hiphop önfeledt élvezetét és a zenében való elmerülést látva Julius feladja, hogy a fiatalokhoz a fekete szenvedés képét társítsa. Be kell ismernie, hogy a fiatal ruandaiak éppen: „Olyanok voltak, mint a fiatalok bárhol” (Cole 2012, 139). Ô volt az, aki az estét egyedül tölti, és nem válik szerves részévé a „koreoszonikus”11 közösségnek, melyet a zene, a hiphop ritmikus intenzitása tart össze. ${ }^{12}$ Annak ellenére, hogy nem csatlakozik a táncolókhoz, üdvözli a fekete társas lét kollektív, testesült, improvizatív formáit, melyeket a következőképpen jellemez: „Az ártatlanságuk kifürkészhetetlen és megszokott volt" (Cole 2012, 139). Ezek a formák lehetôvé teszik számára, hogy megkérdőjelezzen internalizált raciális sémákat: akár a liberális, szimpátiára épülő azonosulást a ruandaiakkal, akár azt, hogy - mint magukat elfedő gyilkosokat - elítélje őket: „Ök is ölhettek [...] és csak később tanulták meg, hogy kell ártatlannak látszani” (Cole 2012, 139).

${ }^{11}$ Ashon Crawley kifejezése hangsúlyozza, hogy a fekete performanciában a hang és a mozgás mindig kölcsönösen konstitutív viszonyban áll egymással (2017).

12 Úgy tûnik, hogy - Cole-lal szemben - Julius nyugatosított nigériai értelmiségiként megveti a fekete zenei kultúrákat. Például azt állítja, hogy nincs „érzelmi kapcsolata” a jazzel (Cole 2012, 24). 
Ahogyan a parti - Christina Sharpe kifejezésével élve (2016, 22) „vizuálszonikus” emléke összefonódik a templomban porszívózó fekete nőével, Julius gondolatai, itéletei átalakulnak: „Azt gondoltam, talán ő is azért van Belgiumban, hogy felejtsen [...] És a menekülése esetleg nem attól van, amit csinált, hanem amit látott" (Cole 2012, 140). Elidegenedése ellenére a hiphop zenéjében való elmerülés emléke megtöri az éles különbséget közte és a ruandaiak között. Juliust, a nőt a templomban és a szórakozó fiatalságot, az egész afrikai diaszpórát összeköti a koreoszonikus jelenségek által kiváltott elmélyedés. Julius a diabolusba és a hiphopba, a dolgozó nő a munkába ${ }^{13}$ és a fiatal férfiak a táncoló nők gyönyörü testébe feledkeznek bele: „A fiatal férfiak [...] nyilvánvalóan elmerültek [absorbed] a gyönyörű fiatal nők mozgó testében" (Cole 2012, 139). Julius egy olyan diaszporikus identitást képzel el, melyet a menekülés és a feledés iránti közös vágy, a feledés aktusai táplálnak ${ }^{14}$ (Cole 2012, 140). Ezek a koreoszonikus, performatív jellegű aktusok a feledés felé orientálódnak, összekötik a diaszpórát a tritonuszos és ritmikus zenék, valamint a zajok megélésében és gyakorlatában. A feledést nem az afroamerikai irodalomban elkerülhetetlen emlékezés ellentétpárjaként, hanem Sharpe kifejezésével élve, egyfajta feledés felé orientált emlékezésként (memory for forgetting) indokolt értelmezni, hangsúlyozva ezzel az emlékezés és a feledés kettős, illetve egymástól elválaszthatatlan természetét $(2016,11)$. A regénybeli flâneur halló gyakorlata ugyanis központi szerepet tölt be az emlékező, illetve feledő aktusokban: a feledésbe merülő atrocitások emlékét hozza a felszínre, megteremtve az urbánus helyszínek és bizonyos marginalizált közösségek között létező rejtett kapcsolatokat. Ugyanakkor a feledés védelmet nyújt Julius fájdalmas emlékei ellen, képes blokkolni, meg nem történetté tenni az elfojtani kívánt etikátlan, bűnös tetteivel való szembesülést.

A diabolus, a hiphop auditív befogadása és a szótlanul dolgozó afrikai nô látványa, a szonikus és vizuális hatások együttese lehetôséget teremt arra, hogy Julius fekete perspektívából meghallja a némán dolgozó nőt és a történetét. Julius megerősíti a nő megismerhetetlenségét és a hétköznapi tevékenységének, porszívózó performanciájának homályosságát. Beismeri, hogy soha nem fogja megismerni a néma, zárkózott nő „titkait”, így ahelyett, hogy hangot adna neki, a nevében, helyette beszélne vagy rákényszerítené a megismerhetőség, az átláthatóság nyugati követelményét, megérti, hogy a zajprodukciója és a hallgatása a homályosság, a másság

${ }^{13}$ Julius megfogalmazásában: „A nő folytatta a munkáját, teljesen belemerült [fully absorbed]” (Cole 2012, 138).

${ }^{14}$ Jelen tanulmányban terjedelmi korlátok miatt nem térek ki annak a kérdésnek a vizsgálatára, hogy Julius viszonya anyjával és nagyanyjával miért romlott el, vajon tőlük való elidegenedése és az Amerikába való menekülés összefüggésbe hozható-e a tinédzser korában elkövetett nemi erőszak elfojtásával. 
megközelíthetetlenségének kifejeződése. Amint megismerhetetlenségéről a szubjektivitás keretei között elmélkedik, nem tud ellenállni annak a késztetésnek, hogy a felismerést a fehér nőkre is kiterjesztve a női nem megismerhetetlenségét univerzális sajátosságként értelmezze. A hasonlat nyelvi eszközének felhasználásával „kifehéríti” a fekete nőt, testét kicseréli egy fehér nőére: „titkainak teljes birtokában volt, mint azok a nők, akiket Vermeer ugyanabban a szürke, alföldi fényben festett le; ugyanúgy, mint azoknak, az ő némasága is teljesnek tűnt” (Cole 2012,140). Míg a szonikus elemek képesnek bizonyultak arra, hogy körvonalazzák a fekete nő figuráját és ezáltal túllépjék a raciális nyalábok határait, addig a vizuális séma reprodukálja az ember és a feketeség közötti antagonizmust. A szonikus érzületek, a képzelet és a kapcsolatiság közötti összefüggések miatt a fekete flâneurség etikai lehetôségei alapjában egy halló, nem pedig egy látó gyakorlatra épülnek.

\section{Az indigén kutató és a feminista tüntetők beszédaktusai}

A fehér férfi flâneurrel ellentétben Juliust halló beállítottsága összeköti néhány páciensével és néhány járókelővel. A következőkben arra keresem a választ, hogy Julius kihez kapcsolódik affektív és szonikus szinten egyaránt. Az egyik ilyen betege V., a bennszülött kutatónő, akinek az amerikai telepes gyarmatosításról és az amerikai indiánok genocídiumáról szóló írásai nyomot hagynak mentális egészségén, olyannyira, hogy öngyilkosságot követ el. Depressziója részben munkájának tudható be, illetve annak a felismerésnek, hogy a telepes kolonialista államban az indiánok továbbra is szenvednek. V. megfogalmazásában: „Nem tudok úgy tenni, mintha nem az én életem lenne [...] ez az én életem. Nehéz abban az országban élni, mely eltörölte a múltadat" (Cole 2012, 27). Ahhoz, hogy Julius meghallja V. szenvedését, bizonyos értelemben le kell tennie logocentrikus fegyvereit és az intellektuális pózolást - nem redukálhatja V. fájdalmát a pszichoanalízis tárgyává. Julius szavaival élve „együttérző gyakorlatra” van szükség, mely megköveteli, hogy Julius tekintetbe vegye a különböző hatalmi és elnyomó struktúrák közötti dinamikus kölcsönhatást (Cole 2012, 204). Ez az interszekcionális megközelítés megvalósul, amikor így írja le az egyik terápiás ülésüket: „Elcsendesült, és a szavai által keltett érzet - emlékszem arra, hogy hajszálnyi változást éreztem a szoba légnyomásában - elmélyítette a csendet, úgy, hogy mindketten hallhattuk az irodaajtómon kívüli jövést menést" (Cole 2012, 27). Látható, hogy az interszekcionalitás fogalmát középpontba helyező megközelítés egy hozzá kapcsolódó új odahallgató pszichológiai módszertant eredményez. A férfi terapeuta belemerül, átveszi V. hangjának vibrációs frekvenciáját. Hallgatásával megtiszteli, óvja azt a materiális fájdalmat, mely megtöri V. beszédét. Feladva heteropatriarchális kiváltságait, Julius meghallja 
azt a beszédregisztert, érzi azt a vibrációt, melyet V. szavai keltenek. Brandon LaBelle megállapítása szerint a hang(zás) és a vibráció a beszédpartnerek között létrejövő intim kötelék eredménye: „egy társas viszony, mely súrlódásként és tapintható érzésként kiterjeszti a levegő által továbbított hullámot a materiális világba" (2010, 133-4). A hang érzete rezgésként fokozza a csendet, az interakcióban résztvevők testét a tapintási és az affektív energia kibővített mezőjébe foglalja. Ismeretes, hogy a szociolingvisták nézőpontjából a csend nem feltétlenül állítja meg, illetve rekeszti be a társalgást: megvalósulhat éppen a dialógus nyitvatartása érdekében is (1. pl. Jaworski 1993). Az őslakos tudós és a közelmúltbeli nigériai bevándorló a vibrálás szintjén gyakorolja az egységességet, és megpihennek az amerikai társadalmon kívüliség csendjében. Kommunikációjuk tehát az egyik oldalon a csend, a másik oldalon pedig az eltűntek frekvenciája felé fordul.

Egy másik alkalommal Julius a Battery parkban sétálva a popzenében beállt csend következtében meghallja a park másik végén játszó hangszer hangját. Cole ebben az epizódban rendkívüli részletességgel és pontossággal tudatosan végigvezeti az olvasót a hangtájkép dinamikus és komplex érzelemés jelentésképzési folyamatának egymásra épülő fázisain: homályos hangérzékelés; esztétikai, érzelmi hatások; szociokulturális háttérismeretek előhívása; további tudati asszociációk. Amikor először hallja, az érzékelés szélén lebegő, akuzmatikus hangban ${ }^{15}$ nincs semmi határozott. Ez az akuzmatikus hang először dekontextualizáló jellegű, később azonban újrakontextualizálja a park hangtájképét. A hangforrás azonosításához el kell haladnia a gyermekek zaja és hintáik nyikorgása mellett, majd el kell helyezkednie az erhu játékosok és az énekes környezetében. Itt a hangszer tiszta, halk, vékony hangja jól hallható, szabadon zenghet, nem kell versenyeznie például a metró átütő zajával. Julius értő odahallgatása elindít egy jelentésképző, asszociációs folyamatot. Először számára úgy tűnik, hogy az erhu (kínai hegedû) hangja a V. által tisztelt amerikai indián szellemeket idézi meg: „Az erhu vékony hangja a táncosok magnójából áradó dobok között csúszkált és úgy tûnt, mintha lelki szemeim elé idézte volna azokat a régmúltbeli szellemeket, akiket $\mathrm{V}$. tiszteletre munkásságában méltatott" (Cole 2012, 164-65). A kezdetben akuzmatikus hang nyugtalanító hatása felkelti az őslakosok szellemét: arra kényszeríti Juliust és az olvasót, hogy számot vessen azzal a ténnyel, hogy New York városában szinte nincs bennszülött amerikai. Míg a fehér flâneur az árukapitalizmus fantazmagóriáját felfedi azzal, hogy belelát, többet lát, mint a nyilvános terek eltárgyiasult megjelenése, a fekete

15 Az akuzmatikus hangot anélkül halljuk, hogy látnánk, mi okozza azt (Larousse-t idézi Schaeffer 2017, 64). 
maszkulin flâneur a raciális kapitalizmus és kolonializmus nyomait ${ }^{16}$ világítja meg azzal, hogy átadja magát a hallgatás tevékenységének. Ez a hallgatás stratégiai jellegú, az akusztikus odafigyelés hozzáférést biztosít a raciális kapitalizmusban elrejtett erőszakhoz és ezzel egyfajta posztkoloniális politikát testesít meg. Az „erhu vékony hangjának” kultúrákon átívelő összefonódása a dobok hangjával újrakontextuálizáló, így megidézi Cole Juliusának a szomszédos vámházban a „pauperek és rabszolgák kivégzését”, valamint az amerikai őslakosok erôszakos és visszavonhatatlan megsemmisítésének vibrációs nyomait (Cole 2012, 164).

Bár Juliust szonikus érzékenysége közelebb hozza V. alakjához, a szonikus elemek sem képesek távolságtartását és elkülönülését feloldani. Ha összevetjük V. szavainak és a park hangtájképének Juliusra gyakorolt hatásait, akkor azt a következtetést kell levonnunk, hogy Juliusnak a páciense öngyilkosságára adott válasza nagyon távol áll a gondoskodás gyakorlatait középpontba helyező fekete feminizmustól. Miközben Az erhu és a popzene összefonódó hangjaival az indigén szellem felélesztése megérinti őt és méltatja azt, ezzel szemben meglepi az olvasót azzal, ahogyan megosztja, neutrálisan közli a tényt, hogy V. eldobta saját életét: „Gyászjelentésében, melyet aznap olvastam, a Times azt írta, hogy V. az atrocitásról szemrebbenés nélkül írt. Írhatták volna, hogy látszólag szemrebbenés nélkül, mert az egész sokkal mélyebben megérintette ôt, mint azt bárki gondolta volna” (Cole 2012, 165). A zene segíti abban, hogy meggyászolja V. idő elốtti halálát, és elsirassa a telepes gyarmatosítás utóéletének saját létére és tudományos karrierjére gyakorolt kihatásait. Gyásza azonban azzal, hogy a régmúlt szellemeivel való kapcsolattartás talajába ágyazódik be, lehetővé teszi, hogy megkerülje páciense iránti etikai felelősségének felvetését. Valóban közvetlenül nem felelős páciense haláláért, de mindenképpen aggasztó, hogy a tragikus kifejletben játszott szerepéről elfelejtkezik. Ugyanis miközben Brüsszelben nyaralt, nem teljesítette V. kérését, aki sürgősen beszélni akart vele. A zene bizonyos értelemben megkönnyíti számára, hogy orvosként ne kelljen azzal az etikai paranccsal szembenéznie, amelyet az indigén nő nyomorúsága, halála ró rá. Ahelyett, hogy V. öngyilkosságához kapcsolódóan elvégezné a tőle elvárható, kemény szakmai és érzelmi munkát, melankóliába és spiritualitásba menekül. Így a zenei és szonikus elemek által kiváltott érzelmi reakcióit és bánatát meg kell különböztetni a szakemberként tanúsított etikai magatartásától, aki nem figyelt kellőképpen a segítségért hozzá forduló $\mathrm{V}$. igényeire. Ez a részvétlen magatartás a kószáló flâneurség etikai felelőtlenségével is összefüggésbe hozható.

16 Jodi A. Byrd, Alyosha Goldstein, Jodi Melamed és Chandan Reddy álláspontjához hasonlóan a történelmileg egymást konstituáló kapitalizmust és a gyarmatosítást raciális elnyomó, kisajátító rendszereként értelmezem (Byrd et al. 2018, 2). 
Julius éppen exbarátnőjével, Nadège-vel beszél telefonon, amikor a harlemi éjszakában meghallja egy fiatalokból álló nôi csoport kiabálását. Eleinte a messzirôl jött hangokat zajként érzékeli: „Messziről zajokat hallottam, a kezdetekben alig hallható zajokat" (Cole 2012, 22). A csoport vezetőjének hangja egyre erősebbé válik, de Julius továbbra is azt állítja, hogy a felvonulók szavai értelmetlenek; a szavak által reprezentált jelentés, így maga az ellenállás értelmezhetetlen marad (Cole 2012, 22). A tömeg közeledésével a feminista szlogenek egyre érthetőbbé válnak: „Miénk a batalom, miénk az éjszaka, hivott a magányos hang. Jött a válasz: az. utcák a mieink, vegyï̈. vissza az, éjszakát. [...] Nök teste, nök élete, nem tesszüke ki magunkat terrornak”" (Cole 2012, 23). Ekkor már Julius is kénytelen felfogni a szavak jelentését, de nem érinti meg, hogy a női közösség gyülekezési jogát érvényesítve az oralitás erejével töri meg a csendet, kilép a hangnélküliség dermedtségéből, magához ragadja a szót, és követeléseit artikulálja. Nem látja meg a feminista térfoglalás radikális lehetôségeit. A sípolást furcsa módon nem köti össze a nők ellen elkövetett szexuális erőszak elleni menettel, de azt megjegyzi, hogy a sípok hangja nem vidám, inkább komolyabb, borús: „Néhány sípoló áthasította a levegőt, de ez nem volt egy ünnepi hang [...] Inkább valami komoly" (Cole 2012, 22). A sípok éles hangjai mintegy átszúrják a patriarchátust, azt a levegő́t, melyet mindannyian belélegzünk. Emellett Julius érzékeli, hogy a dobok egyre agresszívabbak, és ez a hangzás előhív benne egy sajátos asszociációt: a nemi erőszak kultúrája elleni fellépést a férfiak vadászatához hasonlítja: „a dobok egyre katonásabb tónust vettek fel (egy vadászó csoportra gondoltam, ahogyan kiűzik a nyulakat az üregeikből” (Cole 2012, 22). Amint elhaladnak az ablak alatt, Julius visszavonul lakásába és bezárja az ablakot, hogy tompítsa a tüntetők lázadó hangjait, és elszigetelje magát feminista követeléseiktől. A mozdulat felfedi a szolidaritás elutasítását; Julius bezárja, illetve visszazárja önmagát a patriarchális értékrendbe. Menedéket keres saját maga számára. Hangosan felolvas, illetve megszemélyesít különböző maszkulin szövegeket. Hangja találkozik a bekapcsolt rádióból származó klasszikus zenei csatornákon áradó muzsikával és a különböző nyelveken felhangzó bemondók hangjával, ami egy „szonikus fúgává” olvadva menedéket keres saját maga számára: „Feltűnt az a furcsa mód, ahogyan a saját hangom elvegyült a francia, német vagy dán rádiós bemondókéval, vagy a zenekarok hegedű húrjainak vékony szövetével"17 (Cole 2012, 5). Ezt megelőzően is,

${ }^{17}$ A fúga „egy fö témát módszeresen imitáló (ellenpontozó) dallamvonalakból épülő, énekes vagy hangszeres zenei műfaj” (Britannica 260). Cole Juliusának „szonikus fúgája” valójában nem „fúga”, de a fogalom kiterjeszti a fúga zenei múfajának jellemvonásait a hanghatásokon alapuló ellenpontos szerkezetekre (beleértve Julius narratíváját és tudatállapotát egyaránt). A fúga a pszichiátriában is használt fogalom: a disszociatív fuga állapotában az önazonosság felbomlik és a beteg az amnézia hatására vándorolni kezd (Vermeulen). A fúga kettős 
amikor ablakából lenézett a tüntetésre lezárta érzékszerveit, szemét és fülét, illetve kognitív felfogóképességét, hogy tudatosan el tudja magát határolni a lent látható, formálódó nôi mozgalomtól. Hasonlataiban érezhető az elhatárolódás, az elutasítás és a vágy, hogy félrehallja, értelmetlen „zajként” értelmezhesse a szonikus együttest. A zaj egyes fragmentumainak interpretálása érezteti azt a makacs törekvést, hogy a hallottakat férfiakat üldöző hajtóvadászatként tekinthesse. Julius attitűdje a lázadó nők iránt emblematikus, amennyiben jól mutatja, hogy nem hajlandó a fekete nőket meghallgatni és ilyen módon a szövetségesükké válni. Ugyanakkor a feminista tömeg hangja, beszéde felhívja az olvasó figyelmét arra, hogy Julius érzéketlensége, negligáló viselkedésre ellenére érdemes a hallottakra odafigyelni és a női követelések komplexitását átgondolni.

\section{Moji, az áldozat/túlélő*18 megnyilatkozása, Mahler és a csend mint alternatív lehetőségek}

Ahelyett, hogy meghallgatná a szereplőket, a feminista tüntetőket, V.t, illetve Mojit, és ezáltal etikai viszonyba kerülne velük, Julius a patriarchátus által ráruházott privilégiumokat inkább beszédaktusaik elutasítására, elnémítására, vagy eltorzítására használja fel. A regény végén Juliust a feledésbe merült gyermekkorához és Afrikához kapcsolódó lány, Moji kísérti. A Union Square egyik boltjában felbukkan Moji, véletlenül találkoznak Juliussal. Julius úgy viselkedik, mintha nem is ismerné a lányt. Szóba elegyednek, néhányszor találkoznak. Moji meghívja őt egy partira, ahol emlékezteti, hogy tizenöt évesen Nigériában egy bulin az akkor tizennégy éves Julius megerőszakolta ôt, most viszont úgy viselkedik, mintha egyáltalán nem is ismernék egymást: „Úgy viselkedtem, mintha nem tudnék róla semmit, mintha ôt is elfelejtettem volna" (Cole 2012, 244). Ez a tény új perspektívát jelent az egész narratíva, Julius személyiségének megítélése szempontjából. A múltjával történő szembesítés, a leleplezés különösen azért sokkoló, mert a narrátor maga egy praktizáló pszichiáter, akinek munkájához elengedhetetlenül szükség van az önismeretre, illetve a mások iránti figyelemre. Önképe hamis, saját emberi és szakmai hiányosságait nem látja, sőt, túlértékeli önmagát, azzal büszkélkedik, hogy ő a szakmáján kívül is

jelentését figyelembe véve, a szonikus fúga e disszociatív állapot kifejezéseként, illetve az emlékezetzavarhoz köthető stresszek, vagy traumák észlelése ellen véd.

18 Patterson és mások nyomán az áldozat és a túlélő dichotómiája kritikájaként, illetve a szexuális erőszak alanya identifikációs jogának tiszteletben tartásaként az áldozat/túlélő* terminológiáját alkalmazom (2016, 40-5). A terminus az áldozat és/vagy a túlélő fogalmai köré szerveződő tapasztalatokat, identitásokat és létformákat indexálja. A csillag e fogalmak, illetve binaritásuk meghaladásának lehetôségeit mutatja fel. 
rendkívül empatikus és figyelmes másokkal. Moji megnyilatkozása dialogikus, az elkövetóvel való interakcióban formálódik. Egyértelmú reakciót vár, de Julius nem ad választ, néma marad, nem világos, hogy egyáltalán meghallja-e Mojit:

[...] Julius, szerintem egyáltalán nem változtál. A dolgok nem oldódnak meg csak azért, mert te elfelejted őket. Tizenöt évvel ezelőtt rám erőszakoltad magad azért, mert megúszhattad, és bizonyos értelemben tényleg meg is úsztad. De a szívemben nem, nem úsztad meg. Túl sokszor elátkoztalak, sokkal többször, mint amennyit össze tudok számolni. És ma, talán nem tennéd ezt, bár én akkor sem gondoltam, hogy meg tudod tenni. Ennek csak egyszer kell megtörténnie. De most mondasz valamit? Mondani fogsz valamit? (Cole 2012, 245)

Julius hallgatása a patriarchális elhallgattatás és gaslighting (az érzelmi manipuláció egy olyan formája, melyben az áldozat emlékezőképessége, észlelése, hitelessége megkérdőjeleződik) egyértelmű jeleként értelmezhető. Hallgatásával visszautasítja és ezzel meghiúsítja a párbeszéd további menetét. A hallgatás és Moji hangzó feminista diskurzusa között kialakuló ellenpontos összjáték viszont odahallgatásra készteti az olvasót. Salomé Voegelin szerint a hallgatás éppen azért, mert hallgatásra ösztönöz, alapja lehet egy szonikus alanyok közötti „esetleges és múló cseremódnak” (2010, 87). A hallgatás és a szonikus szubjektum közötti kapcsolat fényében Julius hallgatását felfoghatjuk úgy is, mint az odafigyelésre való felhívást: a hangzás szonikus materiális mivolta a másik, illetve a másság megfoghatatlanságát, az áldozat/túlélő* átélt élményét idézi meg. Az áldozat/túlélő* narratíva szonikus keretezése és átkeretezése olyan látás-, hallás- és olvasásmódot eredményez, mely képes megragadni azt (vagy legalábbis utalni arra), ami kívül marad a kereten. A narratívában a nemi erőszak sem korábban, sem később nem kerül szóba. Moji állítása megtöri a csendet, totális meglepetés, az olvasót sokként éri. A megnyilatkozás, szavainak megfeszített, megtört tónusa visszhangzik a csendben (hasonlóan Mahler 9. szimfóniájának végéhez a zene és a taps közötti intervallumban), mely körülveszi, úgymond körbe öleli megnyilatkozását. Moji hangját és tónusát a narrátor így írja le: „A halk és egyenletes hang, az inflexió teljes hiányában érzelmes [...], amelynek hangereje soha nem nőtt, mostanra feszült, összetört tónust kapott" (Cole 2012, 244245). Azzal, hogy Julius válasza hiányzik, illetve a feminista monológ hatására megszakad patriarchális tudatfolyamának megállíthatatlan áradata, a férfi privilégium megkérdőjeleződik, és ezáltal hallhatjuk az áldozat/túlélő* tompa hangját a szexuális traumára adott válaszként. Mivel Moji beszéde Juliusnak volt címezve, a férfi hallgatása válaszként is értelmezhető. Julius némasága egy olyan olvasat felé irányítja az olvasót, mely abból próbál egy történetet 
felvázolni, ami kimaradt a narrációból (Cole 2012, 9). Ezt kívánom tenni a jelenettel, melyben Julius a Berlini Filharmonikusok Carnegie Hall koncertjét látogatja.

Zeneszakértők szerint a 9. szimfónia Mahler kései stílusát testesíti meg, amikor a szonátát elhagyja az ellenpontért (Rothkamm 2007, 495; Adorno 1996, 95), így az Cole ellenpontos narratívstruktúrájának zenei megfelelője lehet. Pieter Vermeulen a következőképpen jellemzi Cole fúgás narratíváját: „Az egyes elemeket [...] nagyon különböző, sőt ellentétes elemek ellensúlyozzák, [...] az olvasóknak visszhangok, ellentétek virtuális hálózata, a különböző területek közötti mindenféle összekapcsolódások maradnak" (2013, 45). A szimfónia Mahler búcsútrilógiájának részét képezi; a halállal és az élettől való elbúcsúzás tematikájával foglalkozik (Rothkamm 2007, 495, 502). Kései művei Julius szerint is, a Mahlert övező tragédiák ellenére tele vannak fénnyel és életigenléssel: „A mindent elsöprő benyomás a fény: a szenvedélyes életéhség fénye, a halál könyörtelen közeledését szemlélő szomorú elme fénye" (Cole 2012, 250).

Julius úgy érzi, hogy a zenével sikerül a mindenséggel egy hullámhosszra kerülnie, a zenét túlvilági lehetőségek tárházának tartja, ugyanakkor a fehér tekintet megszakítja a szenvedélyesen fülelő és magamutogató flâneurségét. Miközben a zene megtermékenyíti képzeletét, Mahlerrel identifikálódik. Azonosul Mahlernek betegsége ellenére végzett hősies munkájával, végső hazautazásával és Bécsben bekövetkezett tragikus halálával. Mahler zenéjéről a következőt mondja: „Mahler zenéje nem fehér vagy fekete [...], és kérdéses, hogy kifejezetten emberi-e, nem egyetemesebb rezgésekkel van-e összhangban” (Cole 2012, 252). Az ezekben az univerzális vibrációkban rejlő lehetetlen lehetőségek egyfajta formális és időbeli szakadást előidézve „különböző episztemológiai, talán már ontológiai és empirikus rezsimek felé mutatnak" (Keeling 2009, 567). Az álombeli, a világot másképpen képzelő harmadik tétel (Crawley szavaival élve) imagines otherwise, egy példája a mahleri legtávolabbi zene, a „Musik aus weitester Ferne” kategóriájának (Rothkamm 2007, 509). Az alteritást kifejező zene az áldozat/túlélő* narratívájának nyomaként is értelmezhető, ${ }^{19}$ egy olyan más világ közvetítőjeként, melyben a fekete (női) életek is számítanak. A zenében transzformált formában ezt a szublimált üzenetet már Julius is kész meghallani.

${ }^{19}$ A tritónusznak itt is fontos szerepe van, kiváltképp a halál bizonyossága és az élni akarás közötti konfliktus kifejezésében (Baragwanath 2004, 32). Ahogyan korábban a tritónusz Julius képzeletében az atrocitásoktól menekülő fekete takarítónő hangjaként, itt a tritónusz az áldozat/túlélö* narratívájának nyomaként is értelmezhető, mely paradox módon, Juliusban a tagadás iránti vágyat ébreszti fel és erősíti. 
Theodor Adorno filozófus és zeneesztéta a következőket gondolja a zene és a szünet kapcsolatáról: „A zene mindig és mindörökké formája egy elemeként a szünetet használja/használta" (2002, 625). Cole ezzel a kapcsolattal játszik, amikor a csendet zenei ágenssé teszi, ${ }^{20}$ amikor a szimfónia a zene elhallgatása után még visszhangzik és lüktet a teremben:

A zene elhallgatott. Tökéletes csend a teremben. Simon Rattle még mindig a dobogón állt, a dirigensi pálca még mindig a levegőben, és a zenészek is mozdulatlanok, hangszereik a kezeikben. Körbenéztem a teremben, a megvilágított arcokra, amelyeket mind elárasztott ez a csend. A másodpercek elhúzódtak. Senki sem köhögött, és senki sem mozdult. A termen kívülről messziről hallhattuk a forgalom halk hangját. De benne egy hang sem: a gondolatok százai is megálltak. Aztán Rattle leengedte a karját, és a nézőtér tapssal robbant fel. (Cole 2012, 254)

A tökéletes csend megtölti az akusztikus teret, és hallhatóvá teszi a halk hétköznapi neszeket, zörejeket. Voegelin megállapítása szerint a csend nem a hangok hiányát, hanem a hallgatás és a zaj kezdetét jelenti, mely a hallgatókat szonikus közösséggé alakítja (2010, 83). A csend a teremben tehát a hallgatás és a zajképzés kezdete. Kiiktatja a hallgatók megszokott gondolatainak menetét és leállítja a testi mozgásokat, amikor a külső zajok megjelennek, a belső csend fogva tartja őket. Annak ellenére, hogy a hallgatóság foglyul ejtése a csend, a pauza által mulandó, a nyitottság, melyet az ilyen kollektív hallási élmények eredményeznek, a közösségben megélt társas revelációk és lehetőségek alapja lehet.

Mahler zenéje megalapoz, létrehoz egyfajta szonikus kapcsolatrendszert, amely a másságot (akár a fekete női másságot) is magában foglalja. Ugyanakkor ez a rassznélküli vagy rasszon túli zenei élmény nem képes arra, hogy a koncertterem halljában megváltoztassa a tér és a szubjektivitás raciális és gender alapú strukturáltságát. A koncerten Juliusnak feltünik, hogy: „Mint szinte mindig, az ilyen koncerteken, szinte mindenki, fehér volt” (Cole 2012, 252, 251). A szünetben észreveszi, hogy sorban álláskor sokan nagyon furcsán néznek rá. ${ }^{21}$ A fehér marginalizáló,

20 A csendről szóló diskurzust nagymértékben befolyásolja John Cage 4’33” (1952) néma darabja, amely bevezette a csendet a koncertterembe (bővebben ld. pl. Voegelin 2010, 80-81). ${ }^{21}$ Black Skin, White Masks címú művében Fanon a következőket állítja $(1968,140)$ : „Nem tudok elmenni egy filmre, anélkül, hogy ne lássam magam. Várok magamra. A szünetben, mielőtt elkezdődik a film, várok magamra. A moziban az emberek engem néznek, engem vizsgálnak, várnak rám. Egy fekete szolga fog megjelenni. A szívverésemtôl elszédülök." Julius racializált tapasztalatai a koncertterem fehérek által dominált terében felfoghatók akár Fanon megjegyzéseinek zenei-szonikus perspektívából való regényesített átdolgozásként is. Terjedelmi korlátok miatt nem áll módomban kitérni a különbségekre Cole és Fanon 
lealacsonyító tekintetek megsemmisítik önazonosságát, aktiválják benne a fehér szupremácia értékrendjét, melynek szemszögéből látja önmagát. Olyan érzése támadt, mintha Ota Benga lenne, az a Mbuti férfi, akit 1906-ban a bronxi állatkert majomházában állítottak ki (Cole 2012, 252). A szünetben az érzékszervei által közvetített indulatok keltette érzületek és az általuk kiváltott normatív fizikai és pszichológiai reakciói megsemmisítik a szimfónia által létrehozott túlvilági rassznélküli közösséget. Az ábrázolás és a láthatóság tartománya visszaküldi Juliust, a fekete flâunert a fekete lét lehetetlenségeibe, megszakítja azonosulását a fehér művész férfival, visszazárja ôt a koloniális időbeliség és térbeliség „pokoli körforgásába”, melyből nincs kimozdulás az univerzális emberi jövő felé (Fanon 1968, 140).

Az ellenpontos narratívában a mahleri klimaxot és a büfés antiklimaxot követően, Julius egy rendkívül komikus helyzet áldozatává válik. A vészkijárat becsukódik Julius mögött, aki hirtelen a Carnegie Hall épületének megvilágítatlan oldalán találja magát a zuhogó esőben. Az égboltot fürkészve elismeri, hogy nem éri el a csillagok fényét, mert: „egész lényem egy vakfoltban ragadt meg"22 (Cole 2012, 256). Julius a Mojin elkövetett nemi erőszak emlékét, magát a bűnt vakfolttal takarja el, és a flâneur barangoló tekintete elől, illetve a füle mögött rejtegeti, így „teljesen felderíthetetlen, rejtett férfi" marad (Benjamin 2002, 420). Egyébként maga Julius is a pszichiáterek munkáját egy olyan „,széles vakfolthoz hasonlítja, amely eltakarja a szem nagy részét", mert a betegek által elmondottakra támaszkodva, gyakran ők is ezen a hiányos, torzító lencsén keresztül látják a tüneteket, miközben a lencsének a mikéntje „gyakran maga is szimptomatikus” (Cole 2012, 239, 238). Később viszont, amikor Julius a saját elméjét Moji vádjával összefüggésben veszi górcső alá, akkor úgy látja, hogy mindenkinek abból kell kiindulnia, hogy a saját elméje „nem lehet teljesen átláthatatlan” (Cole 2012, 243). Elismeri ugyan, hogy Moji nem egy rosszul elképzelt, nyilvánvalóan hamis, szimptomatikus narratívát ad elő, de belekapaszkodik a mintha szó bizonytalanságot indexáló jelentésébe, elégedett, úgy érzi, nem követett el erőszakot: „Ưgy mondta, mintha egész lényével biztos lenne az igazában” (Cole 2012, 244, kiemelés tőlem - M. D.). James Wood értelmezése szerint az

ábrázolásmódjai között; a szünetben való fekete szubjektum, a várakozás és a fehér tekintet összefüggéseiről bővebben l. Keeling 2003.

22 „A vakfolt kb. 1,6 mm átmérôjű, köralakú terület a szem ideghártyáján [...] Ehelyütt hiányoznak a receptorsejtek, tehát itt nincs látás" (Britannica 299). A vakfolt (látókörkiesés) miatt a szem egy része képtelen a fény érzékelésre, ezért a látott kép soha nem lehet tökéletes, de ezt a tényt az agy automatikusan képes leplezni, így az ember nincs tudatában látása tökéletlenségének. A vakfolt szemészeti fogalmát Julius kiterjeszti a tudatra. A tudat igyekszik egy belső ellentmondásoktól mentes, harmonikus önképet teremteni, melynek során a nem kívánatos eseményeket, emlékeket „vakfoltokkal” eltakarja, azaz különféle torzításokkal, elfojtásokkal, téveszmékkel a tudatalatti mélyébe száműzi. 
elkövető és az áldozat között zajló interakció Julius mások megértését akadályozó „önző normalitásának” és „hétköznapi szolipszizmusának” bizonyítéka. Wood nem foglalkozik sem Moji narratívájával, sem elhallgattatásának/visszautasításának etikai vonatkozásaival. Ezzel szemben, Vermeulen állitása szerint Julius rögeszmés sétái és disszociatív állapota arra mutatnak rá, hogy figurája inkább fugueurként (bolond, kényszeres utazóként), mint flâneurként értelmezendő (2013, 53-54). Egyetértek azzal, hogy Julius disszociatív állapotának, illetve a nemi erőszakkal összefüggően akár szelektív amnéziájának vagy szándékos elfedésének, elfojtásának jelentősége van, ugyanakkor véleményem szerint a városképhez füződő viszonyát a flâneurség szempontjából szükséges értelmezni. A nemi erőszakot érintő két narratíva időbeli, térbeli és cselekménybeli szakadást eredményez, a kettős narráció magát a narratívát alapjaiban ambivalenssé teszi. Az első változatban Julius nem tesz említést a nemi erôszakkal kapcsolatos beszélgetésről, de napkelte előtt elhagyja a bulit, és napkeltekor tanúja lesz egy balesetnek a George Washington hídon. A második változatban napkelte után kel fel, és Moji szembesíti ôt múltbeli tetteivel, mielôtt felmegy a hídra. Moji beszédaktusa zenei és narratológiai szempontból egyaránt Julius elbeszélésének ellenpontjaként fogható fel - ahol Moji hangja nem egyszerűen feloldódik Julius hangjában, hanem ellenkezik, „szembeáll vele” (Adorno 2006, 75).

A városi terekben való bolyongásai sokféle, változó identitáslehetőségeket kínálnak számára, önértelmezése időnként megerősítést nyer vagy kibillen, de a sokkoló vád alapvetően megkérdőjelezi azt. Nem képes a kihívásnak megfelelni, a múlttal szembenézni és önképét felülvizsgálni. Ahelyett, hogy korrigálta volna patriarchális vakfoltját, az ellenpont csupán tudatosítja Juliusban, hogy bizonyos tekintetben vak önmagával és másokkal szemben is. Konstatálja, hogy egy olyan vakfoltba került, ahol saját belső énje sötétnek, átláthatatlannak és megfoghatatlannak tűnik, de azt nem látja át, hogy ezt ő idézte elő fekete macsó viselkedésével. Látása egy rövid időre (a Mojival a nemi erôszakról való beszélgetés idejére) kitisztul, hogy azután visszavonuljon a sötétségbe (a későbbiekben semmiféle utalást nem tesz a nemi erőszakra): „Olyan közel kerültem valamihez, hogy az kiesett a fókuszból, vagy annyira messzire kerültem tőle, hogy elhalványult” (Cole 2012, 257). Jared Sexton szavaival élve: „,[ô maga] az a nem szabad dolog, amelyet [nem] ismer és nem tud megoldani” (2017). Azaz Julius nem szabadul fel és nem szabadul meg a gyarmatosítás és a heteropatriarchátus által rákényszerített racializált gendernormáktól és -szerepektől. A bemutatott őslakos és a fekete nők, valamint a tüntetők megnyilatkozásai sem képesek áthatolni privilegizált patriarchális helyzetéből adódó szelektív hallásán, nem adja fel a normatív, áldozatot nem igénylő genderfelfogást. Elzárkózik attól is, hogy a flâneuri bolyongás közben a fülei által közvetített és érzékelt másság 
hatására átértékelje saját megrendült önazonosságát, egyéni defektusokkal küzdő identitászavarát. Nem képes önmagát meghallani, nem tud legbensőbb énjének belsô ellentmondásaival szembenézni. Továbbra sem tud vagy akar visszaemlékezni az elfojtott emlékekre, nem hagyja, hogy emlékezetének folyama a nemfehér nőkkel való szolidaritás felé szabadon áramoljon.

\section{Összegzés}

A nézés és a nézettség iránti maszkulin modernista vágyat kifejező fehér flâneurséghez hasonlóan a fekete flâneurségben is artikulálódik a nézés és a nézettség iránti vágy, de ezen túlmenően szerves összetevője a hallás és az odahallgatás iránti fogékonyság és igény. A fekete fllâneurségnek tehát alapvető jellemzője a „vizuálszonikus” orientáció, mely a rasszista elnyomás és a gender privilégium keresztmetszetében, ambivalens módon, az alávetettséghez és a dominanciához egyaránt kapcsolható tapasztalatok függvényében érvényesül. A fekete flâneur zenei és egyéb auditív, a racializált hallási gyakorlatokon túlmutató élményei felfedik a hivatalos narratívákon kívül maradó városi (hang)tájképek és az ott élő különböző marginalizált lakosok/közösségek traumatikus történelmi múltját és jelenkori szenvedését. A fekete flâneur szonikus érzékenysége azonban általában férfi központú, nem terjed ki a fekete nők specifikus elnyomásának és alárendeltségének szólamaira. Julius elutasítja a feminista tüntetők, illetve Moji áldozati/túlélői* hangos/hangzó megnyilatkozásait, nem hajlandó feladni patriarchális dominanciáját és etikai viszonyba kerülni velük. Julius belső, patriarchális kiváltságok talajában gyökerezô világában a női elnyomás szólamai legfeljebb tünékeny, semmivé foszló rezdüléseket váltanak ki (ld. az ismeretlen afrikai nő zajképzésének és csendjének, valamint V. gyötrelmeit kifejező szavainak vibrációját).

A benjamini maszkulin fehér nézelődő flâneur potenciálját a szonikus élmények jelentésképző folyamatai, a hangokra, zajokra, a zene érzelem és jelentésképző szerepére való odahallgatás, radikálisan megnövelhetik, ami új horizontokat nyit a városi kapitalista lét olvashatóságához, megérthetőségéhez. Nyilvánvalóan a hangtájképek értő hallgatása, a fekete flâneur sem képes megválaszolni a who done it alapkérdését, hiszen a raciális kapitalizmus rendszerszintű bűnbakjait, „bűnözőit” nem lehet olyan egyszerűen kézre keríteni, mint a detektívregényekben. Így annyi azért megállapítható (Theodor Adorno Kafka múveire vonatkozó érvelését kiterjesztve), hogy az Open City is értelmezhető olyan detektívregényként, melyben a bűnöst nem lehet felelősségre vonni (1983, 265). Ugyanakkor a fekete flâneur kószáló, odafigyelő, érzékeny hallása hozzájárul ahhoz, hogy feltérképezze, feltárja a raciális kapitalizmus városi lenyomatait. Cole 
nyilatkozata is megerősíti azt, hogy a regénybeli fekete flâneur New York olyan olvasatát mutatja be, mely szerint a várost ért első megrázkódtatás nem szeptember 11. volt. A regény tehát lehetőséget teremt arra, hogy Juliust, a kószáló flâneurt a nagyvárosi élet detektívjeként vizsgáljuk. Ugyanakkor paradox módon különösen ebben a nyomozó, felderítő szerepben válik nyilvánvalóvá, hogy a regényben megkonstruált fokalizáció hiteltelensége miatt, Julius flâneursége ellenére nem bizonyulhat igazi, jó szimatú detektívnek, hiszen Moji vádjai alapján nem képes leleplezni és felelősségre vonni a tettest (tehát önmagát). A raciális kapitalizmus bû́neit nyomozó detektív énjével ellentétben a nemi erôszak bűntettében Juliust individuumként, a cselekményt megúszó konkrét elkövetőként kell értelmezni. Belső ellentmondásokkal és feszültségekkel terhelt személyiségének következményeként Julius hallását nem a felderítés vagy az emlékezés, hanem a rejtegetés és a feledés vezérli. Átadja magát a flâneur lődörgő hajlamának, barangoló figyelmét olyan auditív jelenségekre fókuszálja, melyekben eltűnik saját maga, feloldódik emlékeinek, valamint etikai felelősségének súlya. Az akusztikus élmények elterelik figyelmét a patriarchátus erőszakos mivoltáról, helybenhagyják, vissza- vagy újraállítják a patriarchális rend normáit, vagy legalábbis normatív olvasatait.

Cole a „,me too” és a „time's up” mozgalmak globális térnyerését és hazánkban is port kavaró kibontakozását megelőzően ábrázolja a nemi erőszak problematikáját, az elkövető és az elszenvedő két totálisan eltérő perspektívája alapján. Julius konok tagadását, a beismerés, a bűntudat hiányát és az érintetlen torz belső önképet a vakfolt metaforája könyörtelenül közvetíti. Egyfelől a gender és a szexuális erőszak kérdéseiben a Julius „vakfoltjai" normatív, heteropatriarchális hallási (és más érzékelési) gyakorlatokra épülnek. Másfelől azonban a nemfehér női szereplők kinyilatkoztatásainak, ellenállási formáinak, túlélési stratégiáinak és egyéb zajos akcióinak ábrázolásán keresztül kikényszeríti az olvasói odahallgatást. A regény kritikus üzenetei az olvasó számára a mú értelmezésének radikálisan más, új horizontját teremtik meg, új relációs lehetőségek és formák feltárására adnak lehetőséget. Emellett a \#Me'Too és a \#BlackLivesMatter korszakában az ún. odahallgatás segíthet nemcsak a regénybeli, hanem a valós urbánus terek rejtett társas-társadalmi, történelmi háttereinek megismeréséhez, illetve az odahallgatást gyakoroltatva a fekete nők, az indigén nők, a nők, és más kisebbségek hangjainak meghallgatására, megértésére, felemelésére ösztönöz minket. 


\section{Felhasznált irodalom}

Adorno, Theodor. 1996. Mabler: A Musical Physiognomy. Trans. Edmund Jephcott. Chicago: University of Chicago Press.

— 1983. Prisms. Trans. Samuel and Shierry Weber. Cambridge: MIT Press.

_ 2002. Essays on Music Trans. by Susan H. Gillespie. Berkeley: University of California Press.

— 2006. Philosophy of New Music Trans. and ed. Robert Hullot-Kentor. Minneapolis: University of Minnesota Press.

Baragwanath, Nicholas. 2004. „Fin-de-siècle Wagner: Parsifal Analysed through Berg's Programme to Mahler's Ninth Symphony." Music Analysis 23 (1): 27-55.

Baudelaire, Charles. 2010. The Painter of Modern Life. Trans. P. E. Charvet. Harmondsworth: Penguin.

Benjamin, Walter. 1997. Charles Baudelaire: A Lyric Poet in the Era of High Capitalism. Trans. Harry Zohn. London \& New York: Verso.

2002. The Arcades Project. Trans. Howard Eiland and Kevin McLaughlin. Cambridge: Harvard University.

Byrd, Jodi A., Alyosha Goldstein, Jodi Melamed \& Chandan Reddy. 2018. „Predatory Value: Economies of Dispossession and Disturbed Relationalities." Social Text 36 (2): 1-18.

Chude-Sokei, Louis 2014. „The Newly Black Americans.” Transition 113: 5271.

Cole, Teju. 2012. Open City. New York: Random House.

Crawley, Ashon. 2017. Blackpentecostal Breath: The Aesthetics of Possibility. New York: Fordham University Press.

Crenshaw, Kimberlé Williams. 1989. „Demarginalizing the Intersection of Race and Sex: A Black Feminist Critique of Antidiscrimination Doctrine, Feminist Theory, and Antiracist Politics." University of Chicago Legal Forum 139-167.

1991. „Mapping the Margins: Intersectionality, Identity Politics, and Violence against Women of Color."' Stanford Law Review 43 (6): 1241 1299.

De Certeau, Michel. 1984. The Practice of Everyday Life. Trans. Steven Rendall. Berkeley: University of California Press. 
Fanon, Frantz. 1968. Black Skin, White Masks. Trans. L. Markmann. New York: Grove Press.

„Fúga”. 1997. Britannica Hungarica Világenciklopédia. VII. Kötet. Budapest: Magyar Világ Kiadó, 260.

Gilroy, Paul.1993. „Living Memory: A Meeting with Toni Morrison.” Small Acts: Thoughts on the Politics of Black Cultures. London \& New York: Serpent's Tail. 175-82.

Glissant, Édouard. 1989. Caribbean Discourse. Trans. Michael Dash. Charlottesville: University of Virginia.

Györke, Ágnes. 2019. „Stories from Elsewhere: The City as a Transnational Space in Doris Lessing's Fiction.” In Jasmina Lukić et al. (eds.) Times of Mobility: Transnational Literature and Gender in Translation. Budapest: CEU Press, 155-170.

- 2017. „Doris Lessing's London Observed and the Limits of Empathy.” Études anglaises 70 (1): 63-77.

Hacking, Ian. 1998. Mad Travelers: Reflections on the Reality of Transient Mental Illnesses. Charlottesville: University Press of Virginia.

Jaworski, Adam. 1993. The Power of Silence: Social and Pragmatic Perspectives. Newbury Park: Sage Publications.

Kandiah, Thiru 1998. „Epiphanies of the deathless native users’ manifold avatars: A post-colonial perspective on the native speaker." In Rajendra Singh (ed.) The Native Speaker: Multilingual Perspectives. New Delhi: Sage Publications, 79-110.

Keeling, Kara. 2003. „'In the Interval': Frantz Fanon and the 'Problems' of Visual Representation." Qui Parle 13 (2): 91-117.

Keeling, Kara. 2009. „Looking for M-: Queer Temporality, Black Political Possibility, and Poetry from the Future.” GLQ 15 (4): 565-82.

LaBelle, Brandon. 2010. Acoustic Territories: Sound Culture and Everyday Life. New York \& London: Continuum.

- 2018. Sonic Agency: Sound and Emergent Forms of Resistance. London: Goldsmiths Press.

Mózes, Dorottya. 2020. „Black Flânerie, Non-white Soundscapes, and the Fantastic in Teju Cole's Open City." HJEAS 25(2). (megjelenés alatt)

Pataki, Éva. 2014. „Mozgásban: a turista és a flâneur Nirpal Singh Dhaliwal Tourism című regényében." Filológia Közlöny 60 (2): 183-197. 
Patterson, Jennifer. 2016. Queering Sexual Violence: Radical Voices from Within the Anti-Violence Movement. New York: Riverdale Avenue Books.

Rothkamm, Jörg. 2007. „The Last Works.” In Jeremy Barham (ed.) The Cambridge Companion to Mabler. Cambridge: Cambridge UP, 494-543.

Schaeffer, Pierre. 2017. Treatise on Musical Objects: An Essay Across Disciplines. Trans. Christine North and John Dack. Oakland: University of California Press.

Sexton, Jared. 2017. „On Black Negativity, or the Affirmation of Nothing." Society \& Space. Letöltés: 2020. december 29.

Sharpe, Christina. 2016. In the Wake: On Blackness and Being. Durham: Duke University Press.

Stoever, Jennifer Lynn. 2016. The Sonic Color Line: Race \& The Cultural Politics of Listening. New York: New York University Press.

„Tritone.” 2003. In Don Michael Randell (ed.) The Harvard Dictionary of Music. Cambridge: Belknap Press of Harvard UP.

„Vakfolt”. 1997. Britannica Hungarica Világenciklopédia. XVIII. Kötet. Budapest: Magyar Világ Kiadó, 299.

Vermeulen, Pieter. 2013. „Flights of Memory: Teju Cole's Open City and the Limits of Aesthetic Cosmopolitanism." Journal of Modern Literature 37 (1): 40-57.

Voegelin, Salomé. 2010. Listening to Noise and Silence: Towards a Philosophy of Sound Art. New York \& London: Continuum.

Wood, James. 2011. „The Arrival of Enigmas.” New Yorker. Letöltés: 2020. december 29. 